arranging the work of cleaning at every moment as it deems best for the general good. It has been found that the cleaning of asphalt streets is particularly more advantageous in the cities' own hands. Next in order come the macadam streets, and the least benefited parts of streets when cleaned by the public are the sidewalks.

A diagram relating to German cities up to 1,000,000 inhabitants shows these results, as well as can be done in figures. There are also given tables stating the areas rerequired for each purpose of the department in the administration buildings, and the number of tools, wagons, and personnel required to do the work upon given areas.

There is given much good advice regarding details of administration, all of which indicates the superior efficiency and economy of permanent bodies, trained for their specific duties and rewarded accordingly.

The book closes with an Appendix containing Answers to Questions submitted to a large number of German cities, regarding the subject matter it was intended to discuss in the book and forming the basis upon which the conclusions therein have been reached.

If a translation of this book were available it should be in the street cleaning department of every city, for it contains more useful information than any other book on the subject that has appeared up to the present time.

\title{
HOUSING, HEALTH AND MORALS IN RICHMOND, VIRGINIA
}

$\mathrm{O}^{2}$

NE of the most interesting discussions at the National Municipal League meeting in Richmond, Virginia, last fall was that on housing, health and morals. It was opened by John Ihlder, field secretary of the National Housing Association, whose address was published in the January number of the Review. ${ }^{1}$ The chairman and the other speakers on the program were, with one exception-President S. C. Mitchel of the University of South Carolina-natives and residents of Richmond, who not only brought out a large amount of new information regarding living conditions in a southern city, but showed their northern visitors that the south is awakening to its social needs. This was particularly true of what Miss Elizabeth Cocke had to say on housing and morals in Richmond and of what Dr. Ernest E. Levy, Richmond's health officer, added in corroboration.

Mr. Ihlder brought out the economic value of sanitary housing and the lack of reliable information in American cities on such vital matters as birth and death rates and the physical effect of insanitary living conditions. Miss Cocke supplemented this by describing the effect of bad housing on the morals of the people, as she had seen it in the course of her work as a nurse.

Our local oonditions in Richmond have, as yet, nothing which approaches the tenement. There are a few old houses occupied by, possibly, some

${ }^{1}$ See vol. 1, page 54. 
half dozen families to the house, but though these show very bad conditions in room overcrowding, there are no conditions of lack of light and air, if the windows are opened to admit ventilation. In one instance I have found a bedroom, occupied presumably by seven people, in which there is no window at all; one door giving upon another room with two windows, and a second door upon the entry on the upper landing.

Among the comparatively small foreign population there is a very great deal of room overcrowding, but the most extensive of these conditions exist among the negroes. These appear to be the most squalid and least progressive, but this I believe to be largely due to the demoralizing effects of bad housing and surroundings which do not tend to any uplift.

Can children raised in Jail Bottom, whose only outlook is a mountainlike dump of rotting rags and rusty tin cans on the one side, and on the other a stream which is an open sewer, smelling to heaven from the filth which it carries along, or leaves here and there in slime upon its banks, have any but debasing ideas? Can parents inculcate high moral standards when across the street or down the block are houses of the "red-light" district? When a dry-closet blocks the one small window of the kitchen, can lack of decency be called to account? Is the world so small that there is no room left for the amenities of life? Are ground space and floor space of more value than cleanliness and health and morality?

It is certainly a fallacy that the poor do not want good housing. In a wonderful address, given last spring at the Child Welfare Conference, in Richmond, a negro speaker said in substance:

"We would use the bath tub as frequently and enjoy it as much as our white brother and sister, if we could afford to rent houses which have the bath tub in them. We do not prefer dilapidation and discomfort, nor being forced to live in districts where there is only depravity and low surroundings; but the better ones of us have too much self-respect to force ourselves on our white brothers, if they do not want us living along side of them."

All that Miss Cocke said was endorsed by the chairman, John Stewart Bryan, who as publisher of one of the most influential newspapers in the south, The News Leader, is in a position to know the facts. "It is an old story to any engaged in work of this sort," he declared, "that a person situated as the negro is in Richmond pays more taxes than the richest man in Richmond, because the taxes he pays take such a large part of his income and he gets so little in return. All that Miss Cocke says is true. They are segregated in Jackson ward, and under a new ordinance they are being still further segregated. That is radically wrong, it is economically wrong, and nothing in the world can change it but an awakening of public sentiment, and it ought to be awakened and it will be."

Dr. Walter S. McNiel, who had made a special study of housing betterment in Germany described the methods used by German cities, especially Frankfort, to provide wholesome homes for the people. "The problem is as big as the interstate commerce question in this country, because as the cities grow it will affect a greater and greater fraction of the total popula- 
tion. As to its solution, he believed that this could not be undertaken by the federal government, at least in the south. It can not be solved by small groups like charity and church organizations or by general benevolence or individuals. "I do not mean" he added, "that any scheme of reform should overlook those factors; they can and do help a great deal. But in the city government only do we find a government so local as to be thoroughly informed as to local conditions and so strong as to be able to combat them."

Dr. Levy, the last speaker, referring to Mr. Ihlder's address, declared that it is easily shown that the prevalence of typhoid is six times as great in a community not sewered as in one that is sewered, that there is a map in the Richmond health department showing that the fatal cases of measles and whooping cough are in general associated with unsanitary surroundings, and that the same is true of diarrhea. "But," he added, "whether this is caused by living in these houses, or whether it is because the people living in these houses are poor people and have poor food and weakened constitutions, I do not know. I think we have a vicious circle here. People live in poor houses because they are poor and they keep poor because they live in poor houses. You have got to break into that vicious circle."

"While I enjoyed Mr. Ihlder's paper very much," he continued, "I confess to a frank disappointment in that he did not suggest a remedy. We may not know what to do unless the specialists tell us, and if he did tell us we would not know what to do unless he showed us."

To this Mr. Ihlder responded that while he had no opportunity to see the hovels described by Miss Cocke he had seen some of the large houses and apartments on the best residence streets and that they showed the need for a remedy he would propose, the enactment and enforcement of a law regulating the percentage of lot area which may be occupied by buildings and requiring that every room shall have adequate light and ventilation. Some of these houses on the best streets occupy from 90 to nearly 100 per cent of the lot. They are built as if they would always, as at present, stand without neighbors, their windows looking out over adjoining property. When the owner of this adjoining property builds the greater part of their rooms will be dark and airless. Even private residences are built closer together than should be permitted in the erection of detached houses.

This comment aroused a number of the Richmond people present who emphatically endorsed it.

New York. JOHN IHLDER.

2 Field Secretary National Housing Association: 